\title{
Dendritic cell vaccine treatment for indolent B cell non-hodgkin lymphoma: clinical trial in progress
}

Yi Lin", Thomas Atwell, Adam Weisbrod, Mary Maas, Adam Armstrong, Michael Deeds, Peggy Bulur, Michael Gustafson, Zhe Zhang, Louis Porrata, Svetomir Markovic, Patrick Johnston, Ivana Micallef, David Inwards, Joseph Colgan, Stephen Ansell, Dennis Gastineau, Allan Dietz, Thomas Witzig

From Society for Immunotherapy of Cancer 29th Annual Meeting

National Harbor, MD, USA. 6-9 November 2014

\section{Introduction}

We present the preliminary results of our clinical trial testing 2 vaccine strategies in patients with indolent $\mathrm{B}$ cell non-Hodgkin lymphoma (NHL; NCT01239875, clinicaltrials.gov). The primary objective is to determine the safety and feasibility of the vaccine approaches and secondary objectives are to describe clinical responses and identify corresponding immune changes.

\section{Methods}

Autologous mature dendritic cells $(\mathrm{mDC})$ were manufactured from leukapheresed cells of NHL patients. For patients with tumor lymph nodes deemed amenable to cryoablation by interventional radiologist ( $\operatorname{arm~A}$ ), they received cryoablation of a node and injection of $\mathrm{mDC}$ into the cryoablated node followed by another 1 to 7 intratumoral $\mathrm{mDC}$ injections. Remaining patients had a tumor excised to generate tumor lysate ex vivo. $\mathrm{mDC}$ were pulsed with tumor lysate during DC maturation (arm B; DC-TL). The DC-TL vaccines were injected intradermally for 4 to 8 doses. Patients are monitored for one year after vaccines for adverse events and systemic tumor response. Correlative studies include cellular immune phenotype of peripheral blood and $\mathrm{T}$ cell intracellular cytokine productions. Planned accrual is 10 patients per arm (total $=20)$.

\section{Results}

To date, 10 patients have accrued to arm A and 5 patients to arm B. All patients tolerated vaccine treatments without major adverse events. Of the 10 evaluable patients, there

Table 1 Patient responses

\begin{tabular}{|c|c|c|c|c|c|c|c|c|c|}
\hline Arm & ID & $\begin{array}{l}\text { Age/ } \\
\text { Gender }\end{array}$ & Histology & Stage & FLIPI/IPI & \# of prior Tx & DC doses & Best response & Time to next treatment or event (months) \\
\hline A & LSA1 & $57 \mathrm{M}$ & Follicular & IVA & 2 & 1 & 2 & SD & 25 \\
\hline A & LSA2 & $56 \mathrm{~F}$ & Follicular & $\| \mathrm{B}$ & 4 & 2 & 2 & SD & 14 \\
\hline A & LSA3 & $69 M$ & Follicular & IVA & 3 & 4 & 2 & PR & 22 \\
\hline A & LSA4 & $60 \mathrm{~F}$ & Follicular & IVA & 3 & 3 & 2 & PR & 20 \\
\hline A & LSA5 & $64 \mathrm{~F}$ & Follicular & IVA & 5 & 8 & 8 & PR & Not reached (12 mo at the time of abstract.) \\
\hline A & LSA6 & $81 \mathrm{M}$ & Follicular & IVA & 4 & 1 & 8 & SD & Not reached (9 mo at the time of abstract.) \\
\hline B & LSB1 & $60 \mathrm{M}$ & Follicular & $\| \mathrm{A}$ & 3 & 1 & 4 & SD & 6.5 \\
\hline B & LSB2 & $62 \mathrm{~F}$ & Marginal zone & IVAE & 4 & 6 & 4 & SD & 7.6 \\
\hline $\mathrm{B}$ & LSB3 & $65 F$ & Follicular & IVA & 3 & 2 & 8 & $C R$ & Not reached (13 mo at the time of abstract.) \\
\hline $\mathrm{B}$ & LSB4 & $31 F$ & Follicular & $\| \mathrm{A}$ & 2 & 0 & 8 & PR & Not reached (12 mo at the time of abstract.) \\
\hline
\end{tabular}


were 1 CR (arm B: 1 / 4; total: 1/10) and 4 PR ( $\operatorname{arm~A:~3/6;~}$ arm B: 1 / 4; total: 5/10) for an ORR of $50 \%$ for both arms (Table 1). Responses have been durable for at least 1 year. Correlative studies suggest that immune changes can be used as prognostic biomarkers to predict response. Upon stimulation, responders' T cells had increased IFN- $\gamma$ and or IL-17a and lower IL-4 production than non-responder $\mathrm{T}$ cells. Preliminary analysis of $>80$ immune phenotypes using flow cytometry and hierarchical clustering suggest that, after vaccination, many components within the immune system of responders change in a different manner from the non-responders.

\section{Conclusions}

Both cryoablation and intratumoral $\mathrm{mDC}$ vaccination are feasible and safe in NHL. Treatment responses may correlate with immune system changes. Biosystems analysis method can be used to develop novel assays as predictive biomarkers of treatment response.

Published: 6 November 2014

doi:10.1186/2051-1426-2-S3-P76

Cite this article as: Lin et al:: Dendritic cell vaccine treatment for

indolent B cell non-hodgkin lymphoma: clinical trial in progress. Journal

for ImmunoTherapy of Cancer 2014 2(Suppl 3):P76.

Submit your next manuscript to BioMed Central and take full advantage of:

- Convenient online submission

- Thorough peer review

- No space constraints or color figure charges

- Immediate publication on acceptance

- Inclusion in PubMed, CAS, Scopus and Google Scholar

- Research which is freely available for redistribution 
